Jurnal Civic Education, Vol. 1 No. 1 Juni 2017

\title{
PEMBELAJARAN PPKn MELALUI MODEL SIMULASI SOSIAL DI SMA NEGERI 1 TONDANO
}

\author{
Apeles Lexi Lonto \\ Dosen Jurusan Pendidikan Pancasila dan Kewarganegaraan FIS UNIMA
}

\begin{abstract}
Abstrak
Penelitian ini diarahkan untuk menemukan model simulasi sosial dalam pembelajaran PKn di SMA. Melalui model ini sasaran yang hendak dicapai ialah: (1) memperkuat pencapaian ranah afektif terutama ranah nilai-nilai sosial, (2) peningkatan suasana dan mutu proses pembelajaran, (3) dampak baik instructional effect maupun nurturant effect, seperti kepekaan terhadap masalah nilai yang terjadi di lingkungan ataupun di masyarakat, kemampuan menganalisis nilai, dan mengambil keputusan terhadap setiap pilihan nilai.

Urgensi penelitian ini didasarkan atas pertimbangan-pertimbangan sebagai berikut: 1). Pendidikan Kewarganegaraan merupakan pendidikan nilai dengan penekanan pada pembentukan afeksi di dalam diri siswa. 2). Praktik pembelajaran PKn di sekolah-sekolah sangat menekankan pada pembentukan aspek kognitif atau ranah kognitif daripada ranah afektif. 3). Proses pembelajaran nilai yang dikembangkan oleh guru-guru lebih banyak dilakukan melalui metode ceramah. Pembewntukan nilai tidak efektif melalui ceramah, tetapi melalui perbuatan atau melalui apa yang dilakukan siswa, dan apa yang dialami oleh siswa itu sendiri. 4). Pembelajaran model simulasi sosial merupakan dalam satu model dalam pembelajaran Kurikulum berbasis kompetensi di sekolah-sekolah. 5). Memperkuat kemampuan atau kompetensi professional guru-guru dalam mengembangkan proses pembelajaran PKn yang lebih varuatif dan inovatif.

Untuk mencapai tujuan-tujuan di atas, maka penelitian ini dilaksanakan dalam bentuk Penelitian Tindakan Kelas (PTK). Analisis data dilakukan secara deskriptif dalam satuan hitung prosentase terhadap ketercapaian indiktor-indikator setiap fokus masalah. Penelitian ini menghasilkan kesimpulan sebagia berikut: (1). Desain model pembelajaran simulasi sosial dalam mata pelajaran PKn di SMA, yang mencakup: analisis kompetensi, asumsi dan tujuan, langkah-langkah pembelajaran, dan sistem pendukung belum berjalan dengan baik. (2). Dampak instruksional pembelajaran terutama dalam pembentukan nilai seperti: kompetisi, kooperasi, empati, sistem sosial, konsep, keterampilan, dan kemampuan berpikir kritis belum berjalan dengan baik. (3). Perbaikan dan peningkatan mutu proses pembelajaran PKn di sekolah-sekolah sangat dibutuhkan.
\end{abstract}

Kata Kunci: Pembelajaran PKn, Model Simulasi Sosial 


\section{Pendahuluan}

Pengembangan desain Instruksional PKn dibutuhkan untuk mengantisipasi dampak lemahnya proses pembelajaran PKn baik di sekolah-sekolah maupun di program studi PKN. Kelemahan-kelemahan tersebut adalah sebagai berikut: (1) Pengembangan tujuan instruksional lebih kuat pada ranah kognitif; (2) Pendekatan metodologis lebih bersifat direktif melalui metode ceramah, dan kurang memberi kegiatan seperti analisis kasus, latihan, simulasi ataupun praktek; (3) Bahan ajar lebih tekstual dengan sumber bahan yang sangat terbatas (buku teks), belum bersifat kontekstual dengan basis lingkungan anak, dan belum memanfaatkan jaringan teknologi komunikasi internet; (4) Pendekatan evaluasi belum komprehensif, karena evaluasi yang dilakukan lebih menekankan aspek kognitif dari pada afeksi dan ketrampilan. Kelemahan-kelemahan tersebut ternyata mempengaruhi baik mutu proses pembelajaran, mutu lulusan, dan sekaligus kemampuan kompetitif rendah yang ditandai dengan waktu tunggu lulusan lama; (6) tantangan masa depan yaitu kebutuhan akan pengembangan model pembelajaran kontekstual (contextual learning) yang membutuhkan suatu desain instruksional, bahan ajar, dan proses pembelajaran yang memberi peluang untuk kegiatan pengkajian dan analisis masalah-masalah aktual. Langkah yang lebih operasional untuk maksud ini adalah memperbaiki bahan instruksional (metode, materi dan kegiatan) sehingga dapat membangun pengalaman komprehensif bagi mahasiswa yang merupakan prasyarat kemampuan mengembangklan pembelajaran kontekstual.

Telah terjadi perubahan dan pergeseran yang sangat fundamental dan ekstensif dalam seluruh aspek kehidupan manusia baik kehidupan politik, ekonomi, social maupun budaya termasuk di dalamnya pengaruh terhadap pendidikan. Perubahan-perubahan tersebut disebabkan oleh globalisasi dan kemajuan teknologi terutama teknologi informasi dan komunikasi. Kemajuan teknologi komunikasi dan transportasi lebih memungkinkan terjadi interaksi pembelajaran yang demikian cepat, dengan dampak yang sangat luas baik positif maupun negatif. Pengaruh tersebut tidak saja berdampak pada proses pembelajaran tetapi juga terhadap isi dan terutama kompetensi lulusan yang harus relevan dengan kebutuhan masyarakat yang sedang berkembang.

Terdapat kecenderungan-kecenderungan yang perlu diantisipasi, terutama pergeseran tuntutan kompetensi guru yang dipersyaratkan oleh UU No 20 tahun 2003 tentang Sistem Pendidikan nasional, PP No 19 tahun 2005 tentang Standar Pendidikan Nasional, dan UU No 14 tahun 2005 tentang Gueru dan dosen. Dipersyaratkan bahwa guru dan dosen harus memiliki kompetensi baik kompetensi kepribadian, kompetensi pedagogik, kompetensi profesional, maupun kompetensi sosial. Kompetensi yang dipersyaratkan tersebut belum sepenuhnya dapat didukung oleh proses pembelajaran PKn yang berlangsung di sekolah-sekolah. Hal ini teramati pada kecenderungan pembelajaran yang bersifat direktif dengan dominasi guru melalui metode ceramah yang mengakibatkan siswa pasif, lemahnya semangat kompetitif, ataupun melemahnya proses pembentukan dan proses internalisasi nilai di dalam diri siswa. Siswa dan guru terjebak dalam suasana rutinitas kegiatan baik belajar maupun mengajar. Artinya tidak atau kurang ditemui upaya-upaya inovatif dan kreatif siswa dalam proses pembelajaran baik di kelas maupun di luar kelas. Di sekolah-sekolah dapat diamati bahwa proses pembelajaran berlangsung sangat direktif, dan berpusat pada guru. Guru menjadi pemeran utama, sementara siswa sebagai pemeran "pembantu", bahkan kurang diberi peran.

Di dalam suatu proses belajar direktif, siswa cenderung belajar menghafal (rote learning) daripada belajar secara bermakna (meaningful learning). Pengamatan empirik terhadap gaya belajar siswa, menunjukkan bahwa siswa cenderung verbalistik, yaitu menghafal tanpa mampu menjelaskan makna dan arti mengenai apa yang dipelajari. Siswa tidak dilatih dan kurang diberi kesempatan untuk mengalami berbagai peristiwa ataupun kejadian yang terjadi di lingkungan dan sekitar siswa. Berbagai peristiwa yang terjadi seperti 
bencana alam, konflik horizontal, pelanggaran hak asasi manusia, berkembangnya budaya kekerasan di tengah-tengah masyarakat, merebak dan belum terberantasnya berbagai praktik kolusi, korupsi, dan nepotisme merupakan fenomena-fenomena yang harus dapat mendorong sikap proaktif siswa untuk menanggapinya. Pembentukan sikap tersebut mengisyaratkan proses pembelajaran yang dapat memberikan kesempatan kepada siswa untuk mengalami secara simulatif. Melalui proses simulatif siswa dapat memahami masalah, mengumpulkan data, dan memberikan alternative pemecahan masalah. Dalam proses simulatif tersebut terjadi proses internalisasi nilai-nilai di dalam diri siswa.

Mengantisipasi berbagai kecenderungan dan mengatasi kelemahan-kelemahan di atas, diperlukan upaya-upaya komprehensif, sistematis, dan sistemik. Upaya itu merupakan upaya yang didasarkan kajian dan implementasi model-model pembelajaran yang inovatif. Sebagai suatu inovasi, model simulasi sosial belum banyak dikembangkan sebagai suatu kegiatan sistemik dan sistematis. Di sekolahsekolah, pembelajaran simulai sosial belum berkembang, sekalipun kurikulum yang dikembangkan (KTSP) mensyaratkan adanya inovasi pembelajaran oleh guru-guru.

Tujuan penelitian ini adalah untuk menemukan:

1) Desain pembelajaran simulasi sosial yang memiliki validitas psikologis, pedagogik, dan sosial sehingga adaptif dengan lingkungan sekolah-sekolah.

2) Sintaks atau lanakgha-langkah pembelajaran simulasi sosial dalam matapelajaran PKn di SMA.

3) Dampak instruksional dan nurturant model simulasi sosial dalam proses internalisasi nilai

4) Faktor-faktor determinan terutama sistem pendukung dalam proses pembelajaran PKn melalui model simulai sosial.

\section{Metode Penelitian}

Penelitian ini dilaksanakan dalam bentuk Penelitian Tindakan Kelas (PTK),

\section{Tinjauan Pustaka}

Pendekatan-pendekatan Pembelajaran PKn

Pembelajaran PKn secara prinsip dapat didekati melalui dua pendekatan yaitu pendekatan yang bersifat deduktif maupun induktif.

\section{1) Pendekatan deduktif.}

Paul D. Eggen, Donald Kauchak, dan Robert Haeder merumuskan pendekatan deduktif sebagai "a thinking process which moves from the general to the spesific" (1979:106). Di dalam praktek pembelajaran, pendekatan deduktif ini diawali dengan kegiatan penyajian konsep atau definisi yaitu suatu kegiatan pembelajaran yang banyak mendominasi proses pembelajaran yang dikembangkan oleh guru-guru. ini lebih banyak digunakan oleh guru-guru. Penyajian defnisidefinisi kemudian diikuti dengan klarfisikasi dan pemberian contoh-contoh. Pendekatan berpikir deduktif dalam model pembelajaran yang dikembangkan ini, dimaksudkan adalah untuk memperkuat dan menjadikan lebih bermakna praktek pembelajaran yang dikembangkan guruguru selama ini terutama dalam mengajarkan dan menjelaskan suatu konsep

\section{2) Pendekatan Induktif}

Pendekatan induktif oleh Paul Eggen, Donald Kauchak, dan Robert Harder dirumuskan sebagai berikut

"Inductive thinking proceeds form the specific to the general. In inductive thinking the individual makes a number of observations which are then processed into a concept or generalization. In inductive thinking, the individual does not have prior knowledge of the abstraction but only arrives at it after observing and analyzing the observations" (1979:110).

Pendekatan induktif sebagai landasan pengembangan model pembelajaran, dimaksudkan sebagai upaya memperkuat praktek pembelajaran $\mathrm{PKn}$, yaitu memberi peluang kepada siswa untuk mencermati fakta dan data, menyusunnya, mengidentifikasi, menganalisis, membuat kesimpulan dan 
penilaian bahkan menguji konsep dan kesimpulan dengan data atau informasi baru.

\section{Tujuan dan Asumsi Pengembangan Model Simulasi Sosial.}

Melalui simulasi ini diharapkan siswa dapat mengembangkan konsep-konsep dan keterampilan yang diperlukan pada suatu penaampilan pada bidang-bidang tertentu. Selain itu dengan simulasi, siswa akan mengetahui akibat yang akan menimpa dirinya bila la memberikan reaksi terhadap respon yang diberikan oleh simulasi tadi, dan mencoba memperbaiki tindakannya. Model simulasi social ini berorientasi pada tujuan. Permainan ini melibatkan siswa pada suatu situasi lingkaran hidup manusia, seperti memilih masalah di lingkungannya: banjir, kebakaran, sampah, bahkan dalam menetapkan pendidikan yang akan diambil. Melalui pilihan yang mereka ambil dalam permainan akan memberikan gambaran dari kehidupan yang sebenarnya.

Model mengajar yang dinamakan sirnulasi, banyak melibatkan pelajaran dengan memanfaatkan perangkat lunak secara efektif. Sedangkan model mengajar lainnya lebih menitikberatkan pada kemampuan pribadi guru seperti; memahami konsep, kemampuan dalam membantu siswa memahami atau menguasai gagasan yang pokok dan lain sebagainya. Di dalam simulasi, guru mengkombinasikan peralatan siap pakai atau perlengkapan simulasi dengan kurikulum, memperjelas dan memperkuat pelajaran yang berhubungan dengan permainan. Guru dapat ikut bermain dalam menunjang pelajaran yang menggunakan simulasi. Penggunaan utama model mengajar ini adalah menggambarkan kegiatan.

\section{Prinsip Cybernetic Pendidikan}

Simulasi telah digunakan lebih dari tiga puluh tahun walaupun bukan merupakan suatu yang asli dari dunia pendidikan. Prinsip ini lebih merupakan aplikasi dari prinsip-prinsip cybernetic (cabang dari psikologi). Konsepsi pelajaran dipandang sebagai sistem umpan balik vang berjalan secara sepontan.

Menurut psikologi sibernetik, tingkah laku manusia mencakup pola gerak yang dapat diamati, baik berupa tingkah laku tak tampak (seperti pikiran dan tingkah laku simbolik) ataupun tingkah laku tampak. Pada bermacammacam situasi yang diberikan, individu memodivikasi tingkah laku sesuai dengan umpan balik yang mereka terima dari lingkungannya. Pola gerak dan responsnya diorganisasikan dengan sistemnya. Kemampuan menerima umpan balik merupakan sistem mekanisme manusia untuk menerima dan menggunakan informasi. Esensi dari psikologi cybernetic adalah prinsip umpan balik yang berorientasi pada pendriaan individual. (Yang dirasakan seseorang merupakan dampak dari keputusannya sendiri) dan merupakan dasar memperbaiki diri. Individu dapat merasakan pengaruh dari ketetapan yang diambilnya akibat dari pemenuhan kebutuhan lingkungan daripada hanya mengatakan bahwa itu benar atau salah dan coba lagi. Ini merupakan konsekuensi lingkungan dari pilihannya yang dikembalikan kepadanya. Belajar dalam pengertian cybernetic adalah penginderaan tingkah laku seseorang yang punya akibat pada lingkungan serta perbaikan diri. Pengajaran dalam pengertian sibernetik dirancang untuk menciptakan lingkungan bagi siswa dengan sistem umpan balik.

\section{Simulasi dalam Pendidikan}

Aplikasi dari prinsip-prinsip cybernetic pada prosedur pendidikan dapat dilihat secara jelas dalam pengembangan simulasi melalui permainan.

Simulasi dikembangkan untuk membantu guru dan siswa dalam tugas bersama untuk merencanakan masa depan, dengan menghadapkan siswa pada banyak masalah dan faktor, seperti: masalah transportasi, sampah, kemiskinan, pasaran tenaga kerja, kecenderungan sosial, sarat-sarat pendidikan dan sebagainya. Melalui simulasi siswa didorong untuk menyadari bermacam-macam masalah, mengevaluasi konsekuensi dari berbagai masalah, dan menemukan alternatif keputusan-keputusan yang dapat diambil. Keputusan-keputusan tersebut merupakan piliah nilai dari berbagai alternative nilai yang ada. 
Model Mengajar Simulasi Sosial.

Model simulasi mempunyai empat tahapan yaitu: Orientasi, partisipasi latihan, simulasi dan tanya jawab.

Tahap pertama: Orientasi. Pada langkah pertama ini guru menjelaskan tema yang akan digarap, konsep yang akan ditanamkan dalam simulasi yang aktual, menjelaskan simulasi.

Tahap kedua: Partisipasi dalam latihan. Pada langkah ini siswa mulai masuk dalam permainan simulasi, guru menetapkan skenario dan memberikan penjelasan tentang aturan permainan simulasinya. Guru mengorganisir siswa ke dalam berbagai variasi aturan dan mempersingkat pelaksanaan untuk meyakinkan siswa dalam memahami setiap arah dan mempergunakan aturan-aturan yang ada.

Tahap ketiga: Simulasi Sendiri. Di sini permainan dan pengadministrasian simulasi mulai berjalan. Siswa berpartisipasi dalam simulasi dan guru berfungsi sebagai wasit dan pelatih. Permainan simulasi dihentikan sementara untuk memberikan kemungkinan bagi siswa menerima umpan balik, mengevaluasi penampilan dan ketetapan yang telah dilakukan dan memperjelas beberapa penyimpangan dari konsep yang sebenarnya.

Tahap keempat: Tanya jawab. Berdasarkan hasil yang telah diperoleh, guru dapat membantu siswa dalam memusatkan perhatiannya pada (1) kejadian, persepsi dan reaksi siswa, (2) menganalisis proses yang telah dilakukan, (3) membandingkan peristiwa dalam simulasi dengan dunia nyata, (4) menghubungkan kegiatan dengan isi pelajaran, dan (5) menilai serta merencanakan kembali simulasi.

Langkah-langkah simulasi sosial

\begin{tabular}{|c|c|}
\hline $\begin{array}{l}\text { Tahap pertama } \\
\text { orientasi }\end{array}$ & $\begin{array}{c}\text { Tahap kedua Partisipasi } \\
\text { latihan }\end{array}$ \\
\hline $\begin{array}{ll}\text { 1. } & \text { Menjelaskan } \\
\text { pokok-pokok dari } \\
\text { tema simulasi dan } \\
\text { konsep yang akan } \\
\text { dituangkan dalam } \\
\text { simulasi yang akan } \\
\text { ditangani. } \\
\text { 2. Memberi contoh } \\
\text { dalam simulasi dan } \\
\text { permainan } \\
\text { 3. } \begin{array}{l}\text { Memberikan } \\
\text { pen jelasan awal. }\end{array}\end{array}$ & 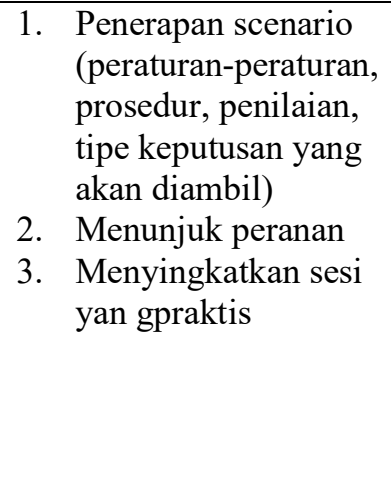 \\
\hline
\end{tabular}

\begin{tabular}{|c|c|}
\hline $\begin{array}{c}\text { Tahap ketiga: } \\
\text { Pelaksanaan simulasi }\end{array}$ & $\begin{array}{l}\text { Tahap keempat: Tanya } \\
\text { jawab }\end{array}$ \\
\hline 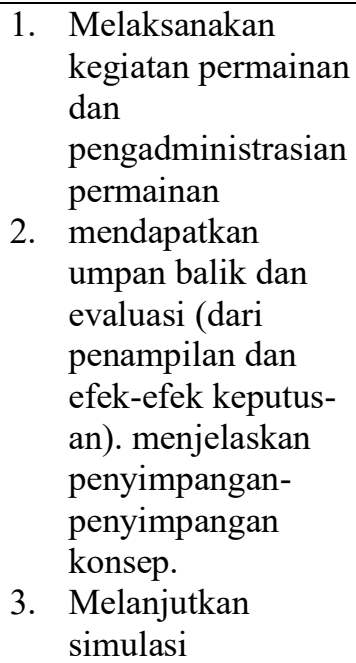 & $\begin{array}{ll}\text { 1. } & \text { Menyimpulkan } \\
\text { kejadian dan } \\
\text { persepsi. } \\
\text { 2. } \\
\text { Menyimpulkan } \\
\text { kesukaran dan } \\
\text { pengamatan } \\
\text { 3. } \\
\text { 4. } \\
\text { Membes analisa } \\
\text { kegiatan simukan } \\
\text { dengan dunia nyata } \\
\text { 5. } \\
\text { Menghubungkan } \\
\text { kegiatan simulasi } \\
\text { dengan isi pelajaran. } \\
\text { menilai dan } \\
\text { merencanakan } \\
\text { kembali simulasi }\end{array}$ \\
\hline
\end{tabular}

\section{Pembahasan}

Kegiatan implementasi dilakukan terintegrasi dengan kegiatan pembelajaran sesuai jadwal di sekolah. Observasi dan refleksi dalam kegiatan induk dan penelitian bagian dilakukan dengan mengacu kepada lingkup masalah masing-masing. Data obersvasi dikumpulkan melalui lembar pengamatan, sekaligus sebagai instrument penelitian.

Berdasarkan hasil penelitian diperoleh bahwa Pendidikan Kewarganegaraan merupakan salah satu bentuk pendidikan nilai. Masalah yang sangat mendasar adalah perumusan kompetensi di bidang afeksi. Analisis terhadap rumusan kompetensi $\mathrm{PKn}$, tampak bahwa guru-guru terjebak pada rumusan kompetensi pada ranah kognitif. Asepk-aepek kognitif sangat dominant dalam rumusan kompetensi daripada ranah afektif pembelajaran PKn. Kondisi ini menyebakan proses pembelajaran berlangsung direktif, dan kurang mendorong siswa aktif dalam pembelajaran.

Kelemahan-kelemahan tersebut lebih disebabkan oleh kemampuan dan kapasitas guru yang belum cukup kuat dalam hal penguasaan model-model inovatif pembelajaran $\mathrm{PKn}$, termasuk di dalamnya kelemahan dalam merumuskan kompetensi ranah afektif. Guru-guru belum cukup kuat dalam melakukan analisis kompetensi ranah 
afektif yang menjadi bobot utama pembelajaran PKn.

Penguasaan dan pengembangan terhadap prinsip-prinsip pembelajaran simulasi social memberi peluang bagi guru dan siswa untuk merumuskan kompetensi afektif dalam pembelajaran PKN. Beberapa prinsip penting ialah guru sebagai fasilitator, supportif, tidak bersifat menghakimi, fleksibilitas, kebebasan interpretasi dan ekspresi, fokus pada masalah ataupun isyu yang relevan, dan evaluasi yang mencakup proses dan dampak pembelajaran. Prinsip-prinsip tersebut masih perlu diteliti dan dianalisis baik mengenai prinsip-prinsip yang diperlukan maupun implementasi prinsipprinsip tersebut dalam proses pembelajaran.

Pembelajaran PKn di sekolah-sekolah baik pendidikan dasar maupun pendidikan menengah umumnya kurang disenangi oleh siswa. Terdapat gejala yang menunjukkan bahwa pelajaran PKn seringkali dijadikan sebagai mata pelajaran hafalan, dan siswa didorong untuk menghafal fakta-fakta. Kondisi ini mendorong siswa jenuh dan tidak menyenangi pelajaran PKn. Artinya masalah mendasar di sini adalah proses pembelajaran yang tidak mendorong siswa untuk aktif dan kreatif. Siswa kurang diberi kesempatan untuk mengkaji sendiri, menanggapi dan mensikapi berbagai masalah di lingkungan sekitarnya, kurang ditumbuhkan perasaan dan kepekaaan terhadap berbagai persoalan di lingkungan. Pembelajaran masih sangat direktif dengan guru sebagai pemeran utama.

Model simulasi sosial dalam pembelajaran PKn merupakan salah satu model yang dijharapkan akan dapat merubah peran guru yang bersifat direktif menjadi seorang fasilitator. Implikasi mendasar dari perubahan ini ialah perubahan peran dan cara belajar siswa, yaitu sebagai pemeran utama dalam simulasi dan permainan interaktif yang dikembangkan. Masih perlu diteliti dan dikaji sejauh mana terjadi perubahan peranan guru, dan deskripsi peranan guru dalam suatu kegiatan simulasi seperti simulasi social dalam pembelajaran PKn di SMA.

Pembelajaran bersifat direktif yang banyak dipraktikan oleh guru-guru PKn di sekolah-sekolah sangat mempengaruhi proses pembentukan kompetensi, terutama kompetensi ranah afektif. Demikian juga pendekatan pembelajaran yang bersifat kognitif sangat mempengaruhi pembentukan kompetensi ranah afektif dalam pembelajaran PKn. Kondisi ini disebabkan oleh karena penguasaan guru-guru mengenai pendekatan ataupun model-model pembelajaran inovatif masih sangat terbatas.

Model pembelajaran simulasi sosial, merupakan salah satu model pembelajaran, yang memeiliki karakteristik utama yaitu memberi peluang terciptanya suatu proses pembelajaran yang mendorong siswa aktif dan mengalami secara simulatif masalah dan atau peristiwa yang terjadi di lingkungan kehidupan siswa. Sebagai suatu model, pembelajaran simulasi sosial akan dapat memberikan dampak pembelajaran atau instructional effect dan dampak pengiring atau nurturant effect.

\section{Kesimpulan}

1) Desain model pembelajaran simulasi sosial dalam mata pelajaran PKN di SMA, yang mencakup (1) analisis kompetensi, (2) asumsi dan tujuan, (3) langkah-langkah pembelajaran, dan (4) sistem pendukung belum berjalan dengan baik.

2) Dampak instruksional pembelajaran terutama dalam pembentukan nilai seperti (1) kompetisi, (2) kooperasi, (3) empati, (4) sistem sosial, (5) konsep, (6) keterampilan, dan (7) kemampuan berpikir kritis belum berjalan dengan baik.

3) Perbaikan dan peningkatan mutu proses pembelajaran PKn di sekolah-sekolah sangat dibutuhkan.

\section{Saran}

1. Perlu pengembangan pembelajaran model simulasi sosial dalam pembelajaran PKn di SMA baik aspek perencanaan, perumusan kompetensi, pengembangan bahan ajar, sistem penyajian, maupun sistem evaluasi.

2. Perlu penelitian tindakan kelas (PTK) lanjut dengan mengambil setting kelas, proses pembelajaran, dan analisis terhadap dampak pembelajaran.

3. Perlu adanya keselarasan antara aspek-aspek perumusan tujuan, materi atau bahan ajar, 
proses pembelajaran, dan evaluasi hasil belajar.

\section{Daftar Kepustakaan}

Achmad Sanusi, 1996, Beberapa variabel Strategik dalam Pendidikan Ilmu Sosial, Mimbar Pendidikan IKIP Bandung.

-------, 1993, Kapita Selekta Pembahasan Masalah-masalah Sosial FPS, IKIP Bandung

-------, 1993, Quo Vadis Pendidikan PKN, Jurnal Pendidikan Ilmu-Ilmu Sosial, No. 2 FPPKN IKIP Bandung.

Barr, Bart, J.L. Shermis, 1997, The Nature of Sosial Studies, ETL Publication, Co New York

Barry K Beyer, 1990, Teaching Thinking in Social Studies Mcmillan Publishing, New York

Bruce Joice, 1998, Models of Teaching, S cience Research Association, Chicago.

David Barr Brooke, 2000, Philosophy of Social Science, Prentice Hall, New Jersey.

Donald Ary, Lucy Cheser, 1999, Introduction to Research in Education, Holt Rinehart and Winston, New York.

Gilliom Eugene, 2000, Social Studies, Mamillan New York

Nu'man Sumantri, 1993, Masalah Pendidikan PKN: Antara Tradisional dan pembaharuan, Jurnal PPKN IKIP Bandung

Paul D. Eggen, Donald Kauchak, dan Robert Haeder, (1979), Teaching Strategies, Prenctice Hall New jersey.

Rischard Gross, 1997, Social Studies for Our Times, John Wiley \& Sons, New York

Stanley Wronsky, 2000, Social Studies and Social Sciences: A Fifty Year Perspective National Council for the Social Studies.

Sudjana, 1992, Statistika, Tarsito, Bandung. 